\title{
TOURIST VALORIZATION OF URBAN TOURISM: THE CASE OF REGIONAL CENTRES IN REPUBLIC OF MACEDONIA
}

DOI: http://dx.doi.org/10.18509/GBP.2017.31

UDC: 338.48-53:911.375(497.7)

\author{
Nikola V. Dimitrov \\ Dejan Metodijeski \\ Faculty of tourism and business logistics, University Goce Delcev - Stip, Macedonia
}

\begin{abstract}
The main subject of this paper is tourist valorization of urban tourism. Urban tourism is one of the biggest promoters of cities, and very important link of local economy connecting various sectors in tourist destinations. Tourists use many urban facilities and services and cities are preparing in advance and plan their tourism policies to meet the tourist's expectations. In this paper, we define urban tourism and tourist valorization. With specifically chosen criteria, a methodology for valorization of the eighth regional city centres in Republic of Macedonia was created. Recommendations for selected cities in the Republic of Macedonia are given based on results from the research and how should the cities and the tourism industry improve development of urban tourism.
\end{abstract}

Keywords: urban tourism, valorization, regions, Macedonia

\section{INTRODUCTION}

Urban tourism comprises tourism activities which take place in the cities, including an interaction between the visitors and the urban environment, which is highly populated [1]. Urban environments offer a geographic concentration of buildings and attractions which are conventionally located and prepared so as to respond to the needs both of the visitors and the resident population. The visitors of urban environments are motivated by various reasons, including culture, business, conferences, events, sports, education, etc. Most often, tourists in cities visit specific zones and not the entire city. Usually, these are the central city areas where most of the tourist resources can be found. A typical feature of this type of tourism is an even seasonality, a high consumption and a relatively short stay period.

We can relate the beginnings of urban tourism to the appearance of the first cities established due to commercial, trade, religious and political factors. Ever since ancient times until the Middle Ages, the number of cities was continuously on the rise, wherein the main factor for the creation of the cities as we know them today was the industrial revolution. Cities today, as a consequence of their economic power, have numerous and versatile hospitality facilities, as well as additional activities used by the tourists [2]. Their connected transport infrastructure, such as airports and railroads, make them accessible as a tourist destination. In terms of the tourists and their experience, the diversity of cities constitutes an opportunity for enjoying versatile activities: older tourists are more drawn to cultural heritage, whereas younger ones are more intrigued by night life and entertainment possibilities. Urban tourism contributes also for changing the international image of certain cities, wherein some cities previously considered as industrial ones have 
recognized tourism as a tool for revitalization and a way to survive in an ever changing world [3]. In urban tourism, knowledge and creativity are more and more accepted as a factor in the definition of the local identity of the site being visited, while their identity is actually what makes them different from other destinations and what the tourists will hold on to as a memory [4]. Big cities have always attracted visitors, but over the recent years city tourism has become increasingly extensive and the economic benefits from the visitors have gained a higher importance. Cities in which the number of visitors is lower also consider tourism as an activity that should be developed and supported [5]. The local authorities, in their efforts to attract a higher number of tourists, in addition to the maintenance of the existing sites, have also developed new attractions [6]. Situations with this type of development may often have an unpredictable outcome. On the one hand, the economic development could be boosted, while on the other hand, the social outlook of the local community could be changed.

\section{METHODOLOGY}

The main purpose of this paper is to make a tourist valorization of the urban tourism in the Republic of Macedonia. There are 35 cities in the country, while eight of them have been elaborated in the text, which constitute regional centres, i.e. focal points of the statistical planning regions. In the existing literature pertaining to tourist valorization, there are many authors who make the valorization on the basis of predefined criteria [7, $8,9,10,11]$. A valorization may be made according to a qualitative or quantitative methodology, such as valorization based upon survey questionnaires for tourists, interviews with tourism workers, supervision methods, descriptive methods referring to the destination itself or other research methods. The majority of the literature related to valorization uses descriptive methods, by means of emphasizing the advantage of certain destinations and an assessment through predefined indicators. The tourist valorization of urban tourism via considering the regional centres for the needs of this paper has been conducted on the basis of a qualitative methodology adjusted to prior researches [12], as well as on the basis of the objective condition of the potentials in the eight selected cities.

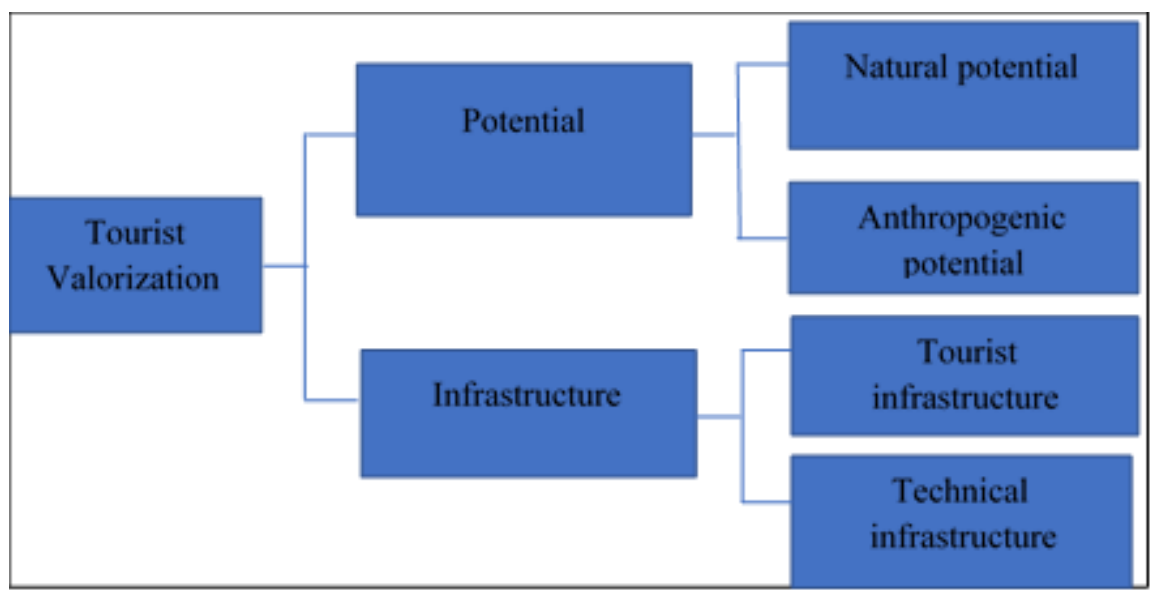

Figure 1. Tourist valorization model (adjusted from Boengiu)

As demonstrated by the model itself, the essence of tourist valorization is the potential (natural and anthropogenic) and the infrastructure (tourist and technical) of the destinations that are subject to the research. The assessment indicators of the regional centres that we deem to be most important at the moment are as follows: 
- the natural potential: mountains, rivers, lakes, mineral springs, weather conditions and parks;

- anthropogenic potential: museums, cinemas, theatres, events, archaeological sites and monuments;

- tourist infrastructure: accommodation facilities, hospitality facilities, travel agencies, accommodation offered on the information system booking.com, a tourism development strategy and a tourism department within the municipality; and

- technical infrastructure: local transport, traffic connections, shopping malls, tourist info centres, published travel guides and sports capacities.

All indicators can be given a minimum of 0 and a maximum of 3 points (depending of their local, regional or national significance), i.e. regarding the natural and anthropogenic potential, as well as the tourist and technical infrastructure, a maximum of 18 points each or a total maximum cumulative result of 72 points. The results obtained from the tourist valorization contribute for the measuring of the tourist potential of the regional centres, which may be classified in a group of the following three types of destinations: a low potential destination with up to 40 points, a medium potential destination with 40 to 50 points and a high tourist potential destination with 50 to 72 points.

\section{REGIONAL CENTRES IN THE REPUBLIC OF MACEDONIA}

The Republic of Macedonia is divided in eight planning regions which serve for statistical, economic and administrative purposes. In addition to the regions, the municipalities constitute the first-instance administrative division in the country. The regional centres are actually eponymous municipalities with the exception of the City of Skopje, which consists of 10 municipalities.

Table 1. Basic data on the regional centres

\begin{tabular}{|l|l|l|r|r|r|r|}
\hline & Region & Website & $\begin{array}{l}\text { Business } \\
\text { entities* }\end{array}$ & Population** & Altitude $(\mathrm{m})$ & $\begin{array}{l}\text { Annual } \\
\text { temperature }\left({ }^{\circ} \mathrm{C}\right)\end{array}$ \\
\hline Skopje & Skopje & skopje.gov.mk & 24.877 & 506.926 & 245 & 13,5 \\
\hline Stip & East & stip.gov.mk & 1787 & 47.796 & 300 & 12,9 \\
\hline Kumanovo & Northeast & kumanovo.gov.mk & 3050 & 105.484 & 340 & 650 \\
\hline Bitola & Pelagonija & bitola.gov.mk & 3897 & 95.385 & 486 & 11,8 \\
\hline Tetovo & Polog & tetova.gov.mk & 3234 & 86.580 & 256 & 11,1 \\
\hline Strumica & Southeast & strumica.gov.mk & 2378 & 54.676 & 206 & 13,6 \\
\hline Veles & Vardar & veles.gov.mk & 1793 & 55.108 & 695 & 13,3 \\
\hline Ohrid & Southwest & ohrid.gov.mk & 2663 & 55.749 & 11 \\
\hline
\end{tabular}

Source: The official websites of the cities. *The data is taken from the Statistical Yearbook of the Republic of Macedonia, 2016. ** The data is taken from the 2002 Census of Population, State Statistical Office of the Republic of Macedonia.

Table 1 comprises the basic data on the regional centres, to which region they belong, the official websites, the number of business entities, the population, their altitude and the annual average temperature. The business entities are given as a parameter that informs us on the business activity in the considered centres. The data shows that in the Republic of Macedonia there are a total of 70,139 business entities, and in the considered urban centres there are 43,679 business entities (with a share of $62,3 \%$ in the total). The position of the population is similar. The population in the Republic of Macedonia comprises $2,022,547$ inhabitants, while in the considered cities the population comprises 1.007 .704 
inhabitants, which means that (49.8\%) almost half of the population of the country lives in these eight cities.

Table 2. Tourist indicators for the regional centres

\begin{tabular}{|l|r|l|l|l|l|l|r|}
\hline & $\begin{array}{l}\text { Number of } \\
\text { tourists } \\
\text { 2015 }\end{array}$ & $\begin{array}{l}\text { Realized } \\
\text { overnight } \\
\text { stays 2015 }\end{array}$ & $\begin{array}{l}\text { Hospitality } \\
\text { facilities** }\end{array}$ & $\begin{array}{l}\text { Number of } \\
\text { seats } \\
* *\end{array}$ & $\begin{array}{l}\text { Accommodation } \\
\text { facilities } \\
* *\end{array}$ & Rooms** & Beds** \\
\hline Skopje & $192.201 *$ & $313.360 *$ & 927 & 34.104 & 69 & 2240 & 5591 \\
\hline Stip & 6997 & 16.472 & 106 & 4369 & 5 & 99 & 181 \\
\hline Kumanovo & 5101 & 10.528 & 206 & 8015 & 10 & 158 & 382 \\
\hline Bitola & 25.512 & 51.374 & 256 & 10.153 & 16 & 481 & 1296 \\
\hline Tetovo & 8666 & 18.964 & 412 & 12.379 & 19 & 394 & 989 \\
\hline Strumica & 24.606 & 54.050 & 161 & 8095 & 9 & 354 & 702 \\
\hline Veles & 8377 & 13.928 & 100 & 4367 & 6 & 227 & 551 \\
\hline Ohrid & 219.926 & 818.175 & 188 & 7592 & 72 & 4538 & 12.422 \\
\hline
\end{tabular}

Source: MAKStat database, State Statistical Office of the Republic of Macedonia. * Data is missing on the municipalities of Shuto Orizari, Gazi Baba, Saraj, Butel, Aerodrom, Gjorce Petrov. *The data is taken from the Census of Catering Trade Capacities, 2008, State Statistical Office of the Republic of Macedonia.

Table 2 provides information on the tourist indicators of the regional centres. In Macedonia, there is a total of 4740 hospitality facilities, with 192,461 seats. In the reviewed regional centres, there are 2356 hospitality facilities with 89,074 seats. Out of the total 486 accommodation facilities that operate in the country, with 16,306 rooms and 45,139 beds, 206 accommodation facilities (with a share of $42.4 \%$ in the total), with 8491 rooms $(52.1 \%$ ) and 22,114 beds (or $49 \%$ ) are located in the regional centres.

In 2015, 816,067 tourists visited the Republic of Macedonia and realized 2,394,205 overnight stays, while the selected cities were visited by 491,386 tourists $(60.2 \%)$ who realized 1,296,851 overnight stays $(54.1 \%)$. More than half of the tourism turnover which is generated in the regional centres comes primarily from the cities of Ohrid and Skopje that are interesting for the majority of the tourists, both domestic and foreign.

\section{TOURIST VALORIZATION OF REGIONAL CENTRES IN REPUBLIC OF MACEDONIA}

Tourist valorization of regional centres in the Republic of Macedonia was conducted in the following eight cities: Skopje, Stip, Kumanovo, Bitola, Tetovo, Strumica, Veles and Ohrid. The selection of the cities for the preparation of the tourist valorization is not random; the fact that they are the centres of the regions in which they belong is a valid assumption that they are leaders in these regions from a cultural, economic and tourist aspect. The tourist valorization was conducted on two bases (potential and infrastructure) and four parameters (natural and anthropogenic potential, technical and tourism infrastructure).

Table 3. Valorization of the natural potential of the regional centres

\begin{tabular}{|l|c|c|c|c|c|c|c|}
\hline $\begin{array}{l}\text { Regional } \\
\text { center }\end{array}$ & Mountains & Rivers & Lakes & $\begin{array}{c}\text { Mineral } \\
\text { springs }\end{array}$ & Climate & Parks & Total \\
\hline Skopje & 2 & 3 & 1 & 1 & 3 & 3 & 13 \\
\hline Stip & 2 & 2 & 0 & 3 & 3 & 1 & 11 \\
\hline Kumanovo & 2 & 1 & 0 & 3 & 3 & 1 & 10 \\
\hline Bitola & 3 & 1 & 2 & 0 & 3 & 3 & 12 \\
\hline
\end{tabular}




\begin{tabular}{|l|l|l|l|l|l|l|l|}
\hline Tetovo & 3 & 3 & 0 & 0 & 3 & 3 & 12 \\
\hline Strumica & 3 & 2 & 1 & 1 & 3 & 1 & 11 \\
\hline Veles & 2 & 3 & 2 & 0 & 3 & 1 & 11 \\
\hline Ohrid & 3 & 1 & 3 & 0 & 3 & 3 & 13 \\
\hline
\end{tabular}

The natural potential of the regional centres is presented via the indicators: mountains, rivers, lakes, mineral springs in the vicinity of the destinations, climate and parks. As we can see in Table 3, the cities have a favourable natural potential for the development of urban tourism. Out of maximum 18 points, Ohrid and Skopje have 13 points each, and the remaining cities have 12,11 and 10 points respectively.

Table 4. Valorization of the anthropogenic potential of the regional centres

\begin{tabular}{|l|c|c|c|c|c|c|c|}
\hline $\begin{array}{l}\text { Regional } \\
\text { center }\end{array}$ & Museums & Cinemas & Theatres & Events & Archaeological sites & Monuments & Total \\
\hline Skopje & 3 & 2 & 3 & 3 & 3 & 3 & 17 \\
\hline Stip & 2 & 1 & 1 & 3 & 3 & 2 & 12 \\
\hline Kumanovo & 2 & 1 & 1 & 2 & 3 & 2 & 11 \\
\hline Bitola & 3 & 1 & 1 & 3 & 3 & 2 & 13 \\
\hline Tetovo & 1 & 1 & 1 & 2 & 3 & 2 & 11 \\
\hline Strumica & 1 & 1 & 1 & 3 & 3 & 2 & 8 \\
\hline Veles & 1 & 1 & 1 & 2 & 3 & 3 & 14 \\
\hline Ohrid & 3 & 1 & 1 & 3 & 3 & & 2 \\
\hline
\end{tabular}

The information on the anthropogenic potential of the regional centres is presented via the indicators: museums, cinemas, theatres, events, archaeological sites and monuments. We can conclude from Table 4 that the cities do not have an equally distributed anthropogenic potential. Out of maximum 18 points, Skopje has 17, Ohrid 14, Bitola 13 points and Veles has the lowest number of points -8 .

Table 5. Valorization of the tourism infrastructure of the regional centres

\begin{tabular}{|l|c|c|c|c|c|c|c|}
\hline $\begin{array}{l}\text { Regional } \\
\text { center }\end{array}$ & Accommodation & Food & $\begin{array}{c}\text { Travel } \\
\text { agencies }\end{array}$ & $\begin{array}{c}\text { Accommodation } \\
\text { on booking.com }\end{array}$ & $\begin{array}{c}\text { Strategy for } \\
\text { tourism } \\
\text { development }\end{array}$ & $\begin{array}{c}\text { Tourism unit in } \\
\text { the } \\
\text { municipality }\end{array}$ & Total \\
\hline Skopje & 3 & 3 & 3 & 3 & 3 & 3 & 18 \\
\hline Stip & 1 & 1 & 1 & 1 & 0 & 0 & 4 \\
\hline Kumanovo & 2 & 2 & 2 & 1 & 0 & 0 & 7 \\
\hline Bitola & 2 & 2 & 1 & 2 & 3 & 0 & 10 \\
\hline Tetovo & 2 & 2 & 2 & 1 & 0 & 3 & 7 \\
\hline Strumica & 2 & 1 & 1 & 1 & 0 & 0 & 5 \\
\hline Veles & 1 & 1 & 1 & 1 & 0 & 0 & 4 \\
\hline Ohrid & 3 & 3 & 2 & 3 & 0 & 3 & 14 \\
\hline
\end{tabular}

The tourism infrastructure of the regional centers is presented via the indicators: accommodation facilities, hospitality facilities (food), travel agencies, accommodation facilities included in the information system - booking.com, a prepared strategy for tourism development and a tourism unit in the local self-government. We can conclude from Table 5 that the cities are not in the same phase of tourism infrastructure development. The small representation of the accommodation facilities registered on booking.com, as well as the tourism development policy, are not very impressive. Only two cities, Skopje and Bitola, have tourism development strategies, and only three cities 
have a tourism unit or department in the local self-government, although all cities have put an accent on tourism in the strategies for local economic development. In this ranking, the City of Skopje has the maximum of 18 points, Ohrid-14, Bitola-10, and Veles and Stip have the lowest number of points -4 .

Table 6. Valorization of the technical infrastructure of the regional centres

\begin{tabular}{|l|c|c|c|c|c|c|c|}
\hline $\begin{array}{l}\text { Regional } \\
\text { Center }\end{array}$ & $\begin{array}{c}\text { Local } \\
\text { transport }\end{array}$ & Traffic & $\begin{array}{c}\text { Shopping } \\
\text { malls }\end{array}$ & Info center & $\begin{array}{c}\text { Travel guide } \\
\text { books }\end{array}$ & Sports facilities & Total \\
\hline Skopje & 3 & 3 & 3 & 3 & 3 & 3 & 18 \\
\hline Shtip & 1 & 2 & 3 & 0 & 1 & 2 & 9 \\
\hline Kumanovo & 1 & 3 & 1 & 0 & 0 & 2 & 7 \\
\hline Bitola & 1 & 2 & 1 & 3 & 1 & 2 & 10 \\
\hline Tetovo & 1 & 2 & 2 & 0 & 0 & 2 & 7 \\
\hline Strumica & 1 & 2 & 2 & 0 & 1 & 2 & 8 \\
\hline Veles & 1 & 3 & 1 & 0 & 3 & 2 & 10 \\
\hline Ohrid & 1 & 3 & 1 & 3 & 3 & 3 & 14 \\
\hline
\end{tabular}

The technical infrastructure of the regional centres is presented through the following indicators: local transportation, traffic connections, shopping malls, tourist info centres, published travel guides and sports facilities. As it can be observed from table 6, the cities are not in the same development phase regarding the technical infrastructure. The low points on the local transportation, as well as the tourist info centres and the published maps, immediately come to attention. In this ranking, Skopje has the maximum, 18 points, Ohrid has 14, Bitola has 10, and Kumanovo and Tetovo have the lowest number of points, 7.

Table 7. Tourist valorization of the regional centres

\begin{tabular}{|l|c|c|c|c|c|c|}
\hline $\begin{array}{l}\text { Regional } \\
\text { center }\end{array}$ & $\begin{array}{c}\text { Natural } \\
\text { potential }\end{array}$ & $\begin{array}{c}\text { Anthropogenic } \\
\text { potential }\end{array}$ & $\begin{array}{c}\text { Tourist } \\
\text { infrastructure }\end{array}$ & $\begin{array}{c}\text { Technical } \\
\text { infrastructure }\end{array}$ & Total & $\begin{array}{c}\text { Tourist } \\
\text { potential }\end{array}$ \\
\hline Skopje & 13 & 17 & 18 & 18 & 66 & High \\
\hline Shtip & 11 & 12 & 4 & 9 & 36 & Low \\
\hline Kumanovo & 10 & 11 & 7 & 7 & 35 & Low \\
\hline Bitola & 12 & 13 & 10 & 10 & 45 & Medium \\
\hline Tetovo & 12 & 10 & 7 & 7 & 36 & Low \\
\hline Strumica & 11 & 11 & 5 & 8 & 35 & Low \\
\hline Veles & 11 & 8 & 4 & 10 & 33 & Low \\
\hline Ohrid & 13 & 14 & 14 & 14 & 55 & High \\
\hline
\end{tabular}

The tourist valorization of the regional centres is presented through the natural and anthropogenic potential, as well as through the tourist and technical infrastructure. The collected data from the touristic valorization give us the opportunity to measure the tourist potential of the regional centres, which can be divided into the following three types of destinations: destination with a low potential, up to 40 points, destination with a medium potential, from 40 to 50 points and destination with a high tourism potential, from 50 to 72 points. As it can be observed from table 7, the cities are not in the same development phase regarding the tourism development. Skopje with 66 and Ohrid with 55 points stand out as destinations with the highest scores and these two cities are the destinations with a high tourism potential. It is expected that these destinations will hold their primacy in the 
near future and continue their tourism development. Bitola, with 45 points, is the only destination with a medium tourist potential and in the future it is expected to aspire towards entering the group of destinations with a high potential. The remaining five cities, Shtip (36), Kumanovo (35), Strumica (35), Tetovo (36) and Veles (33 points), are in the group of destinations with a low tourism potential and they need to focus their energy in bettering the conditions for urban tourism, especially in the areas of tourism and technical infrastructure where they have the lowest number of points.

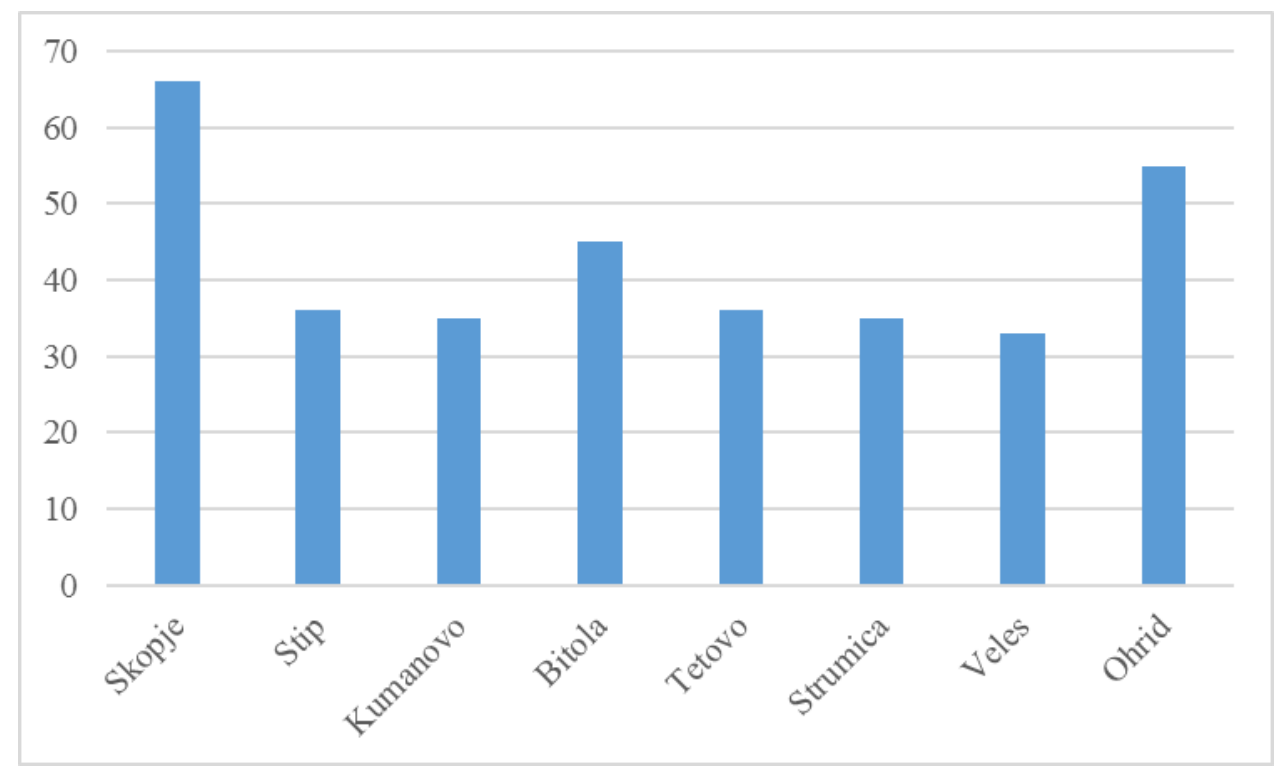

Figure 2. Tourist valorization of the regional centres

\section{CONCLUSION}

Urban tourism is an activity that is being increasingly developed globally. The regional centres in the Republic of Macedonia are destinations which aspire to reach a larger tourism development and benefits for the local communities. The tourist valorization is a method used by the authors in order to evaluate a given tourist destination. In this paper, a qualitative tourist valorization of the regional centres is made, according to indicators which we consider to be the most important for tourism in this moment. A more comprehensive valorization should be made in the future, where more cities and more indicators would be incorporated in order to get a realistic image about the conditions and potentials of the urban tourism in the country. The survey in the paper shows that the majority of the regional centres should invest more energy for a better performance in the sphere of tourism, because only two of the eight analysed cities belong in the category of destinations with a high tourism potential, one city has a medium potential, and five cities have a low tourism potential. The improvement of the tourist and technical infrastructure should be a top priority. The local authorities and the tourism economy should jointly find a way to accomplish this goal through cooperation with all stakeholders for tourism development and through integration and observance of the world trends in tourism. 


\section{REFERENCES}

[1] Metodijeski, D., Cuculeski, N. (2015) International tourism. Skopje: Sovremenost.

[2] Hayllar, B., Griffin, T., Edwards, D., eds. (2008) City Spaces - Tourist Places: Urban Tourism Precincts. Oxford: Elsevier.

[3] Maitland, R., Ritchie, B., eds. (2009) City tourism: national capital perspectives. Oxfordshire: CAB International.

[4] Maciocco, G., Serreli, S., eds. (2009) Enhancing the City: New Perspectives for Tourism and Leisure. London: Springer.

[5] Law, C. (2002) Urban Tourism: The Visitor Economy and the Growth of Large Cities. London: Continuum.

[6] Spirou, C. (2011) Urban Tourism and Urban Change: Cities in a Global Economy. New York: Routledge.

[7] Bjeljac, Ž., Brankov, J., Jovičić, D., Ćurčić, N., \& Terzić, A. (2012) Valorization of natural and anthropogenic tourist potentials in underdeveloped regions of transition countries. TTEM, 8 (3), 1237-1250.

[8] Božić, S., Berić, D. (2013) Tourist Valorization of Cultural Route The Trail of the Roman Emperors. European Researcher, Vol.55 (7-2): 1902-1913.

[9] Kurihara, T., Okamoto, N. (2015) Foreign visitor's evaluation on tourism environment. Journal of the Eastern Asia Society for Transportation Studies, Vol.8: 912925.

[10] Malinic, V., Stevanovic, S. (2015) Tourist valorization of anthropogenic tourist values of the Municipality Lazarevac. Researches Reviews of the Department of Geography, Tourism and Hotel Management, Vol.44 (1): 60-82.

[11] Panov, N. (1998) Tourist valorization of the monasteries in Republic of Macedonia. Skopje: Bato \& Divajn.

[12] Boengiu, V. (2012) Evaluation of tourism resources in the Iron Gates natural park in order to identify the potential of tourism development. Annals of the University of Oradea, Geography Series, Vol.22 (2):234-240. 